\title{
Effect of Nitric Oxide on the Oxygen Metabolism and Growth of $E$. faecalis
}

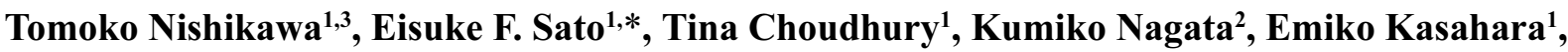 \\ Hiroshi Matsui ${ }^{3}$, Kunihiko Watanabe ${ }^{3}$, and Masayasu Inoue ${ }^{1}$ \\ ${ }^{1}$ Department of Biochemistry \& Molecular Pathology, Osaka City Medical School, 1-4-3 Asahimachi, Abeno 545- \\ 8585, Japan \\ ${ }^{2}$ Department of Food and Nutrition, Senri Kinran University, 5-25-1 Fujishirodai, Suita 565-0873, Japan \\ ${ }^{3}$ Department of Applied Biochemistry, Kyoto Prefectural University, 1-5 Shimogamo, Sakyo-ku, Kyoto 606-8522, \\ Japan
}

Received 9 October, 2008; Accepted 4 November, 2008

\begin{abstract}
Summary Gastro-intestinal mucosal cells have a potent mechanism to eliminate a variety of pathogens using enzymes that generate reactive oxygen species and/or nitric oxide (NO). However, a large number of bacteria survive in the intestine of human subjects. Enterococcus faecalis ( $E$. faecalis) is a Gram-positive bacterium that survives not only in the intestinal lumen but also within macrophages generating NO. It has been reported that $E$. faecalis generated the superoxide radical $\left(\mathrm{O}_{2}{ }^{-}\right)$. To elucidate the role of $\mathrm{O}_{2}^{-}$and $\mathrm{NO}$ in the mechanism for the pathogen surviving in the intestine and macrophages, we studied the role and metabolism of $\mathrm{O}_{2}{ }^{-}$and $\mathrm{NO}$ in and around $\boldsymbol{E}$. faecalis. Kinetic analysis revealed that $\boldsymbol{E}$. faecalis generated $0.5 \mu \mathrm{mol} \mathrm{O}_{2}{ }^{-} / \mathrm{min} / \mathbf{1 0}^{8}$ cells in a glucose-dependent manner as determined using the cytochrome c reduction method. The presence of NOC12, an NO donor, strongly inhibited the growth of $E$. faecalis without affecting in the oxygen consumption. However, the growth rate of NOC12-pretreated $E$. faecalis in NO-free medium was similar to that of untreated cells. Western blotting analysis revealed that the NOC12-treated $E$. faecalis revealed a large amount of nitrotyrosine-posititive proteins; the amounts of the modified proteins were higher in cytosol than in membranes. These observations suggested that $\mathrm{O}_{2}^{-}$generated by $\mathrm{E}$. faecalis reacted with $\mathrm{NO}$ to form peroxinitrite $\left(\mathrm{ONOO}^{-}\right)$that preferentially nitrated tyrosyl residues in cytosolic proteins, thereby reversibly inhibited cellular growth. Since $E$. faecalis survives even within macrophages expressing NO synthase, similar metabolism of $\mathrm{O}_{2}^{-}$and NO may occur in and around phagocytized macrophages.
\end{abstract}

Key Words: Enterococcus faecalis, Superoxide, nitric oxide, peroxynitrite, nitro-tyrosine

\section{Introduction}

Gastrointestinal mucosal cells have potent mechanisms to eliminate a variety of pathogens. Enzymes that generate reactive oxygen species and nitric oxide (NO) are one of the

\footnotetext{
*To whom correspondence should be addressed

Tel: +81-6-6645-3722 Fax: +81-6-6645-3721

E-mail: sato@med.osaka-cu.ac.jp
}

important systems against pathogens [1-3]. In fact, the respiration and growth of $E$. coli were strongly inhibited by NO particularly under physiologically low oxygen tensions similar to that in the intestinal lumen [4]. However, a large number of bacteria survive in the intestine of animals including humans.

Nitric oxide is a multifunctional gaseous radical that binds to iron- and copper-containing proteins with high affinities [5]. Nitric oxide is generated by three types of NO synthases in various cells $[4,6]$, such as vascular endothelial cells 
(eNOS), neurons (nNOS) and leukocytes (iNOS). All the isozymes are expressed in gastrointestinal mucosa $[7,8]$.

Enterococcus faecalis (E. faecalis) is a Gram-positive symbiotic bacterium that survives not only in intestinal lumen but also within activated macrophages [9]. E. faecalis could not grow in macrophage [9]. However, the mechanism by which $E$. faecalis survives in the phagosomes of NOgenerating macrophages is not known. E. faecalis has been known to express NADH oxidoreductase (NOX) that generates the superoxide radical [10]. We previously reported that Helicobacter pylori (H. pylori) generated $\mathrm{O}_{2}{ }^{-}$ through their electron transport chains and that de novo generated superoxide radical reacted with NO to eliminate its bactericidal activity [6]. To clarify the role and metabolism of $\mathrm{O}_{2}{ }^{-}$and $\mathrm{NO}$ in the mechanism for their survival in intestinal lumens and within activated macrophages, we studied the metabolism of $\mathrm{O}_{2}{ }^{-}$and $\mathrm{NO}$ and protein modification occurred in E. faecalis.

\section{Material and Methods}

\section{Materials}

$\mathrm{N}$ - Ethyl- 2 - ( 1 - ethyl- 2 - hydroxy- 2 - nitrosohydrazino)ethanamine (NOC12) was purchased from Dojindo Co. (Kumamoto, Japan). Argon gases and NO were obtained from Kinkisanki Co. (Osaka). All reagents used were of analytical grade and obtained from Sigma Chemical Co. (St. Louis, MO). Nitrotyrosine bovine serum albumin was purchased from Cayman Chemical CO. (Ann Arbor, MI). NO solution was prepared freshly by bubbling NO gas through $50 \mathrm{mM}$ HEPES-NaOH buffer (pH 7.4) as described previously [4]. Two small tubes were fitted with an air-tight septum with glass tubes inserted for delivery and escape of gases with a first and second tubes containing $5 \mathrm{M} \mathrm{KOH}$ and a HEPES-NaOH buffer, respectively. Argon was delivered into the two tubes at a flow rate of $100 \mathrm{ml} / \mathrm{min}$. After $15 \mathrm{~min}$, argon was replaced with $\mathrm{NO}$ at a flow rate of $100 \mathrm{ml} / \mathrm{min}$. After $15 \mathrm{~min}$, the saturated NO solution $(1.9 \mathrm{mM})$ was kept on ice and used for experiments within $3 \mathrm{~h}$; the concentration of NO in the stock solution remained unchanged during the experiments.

\section{Experiments with bacteria}

E. faecalis used in this study was RIMD 5803 (JCM5803) strain. E. faecalis were incubated in BHI medium (Difco) at $\mathrm{pH} 7.5$ and $37^{\circ} \mathrm{C}$ for overnight. The incubated cells $(\mathrm{OD}=0.1$ at $660 \mathrm{~nm})$ were inoculated into $100 \mathrm{ml} \mathrm{BHI}$ medium and cultured with shaking at $\mathrm{pH} 7.5$ and $37^{\circ} \mathrm{C}$ for $4 \mathrm{~h}$. Mid-log-phase incubates $(\mathrm{OD}=0.4-5$ at $660 \mathrm{~nm})$ were obtained and used for experiments. The incubated cells were centrifuged at $3000 \times \mathrm{g}$ and $4{ }^{\circ} \mathrm{C}$ for $10 \mathrm{~min}$, and washed once with PBS.

Oxygen consumption by E. faecalis $\left(1 \times 10^{8}\right.$ cells $\left./ \mathrm{ml}\right)$ was determined polarographically using a Clark type oxygen electrode fitted to a $2 \mathrm{ml}$ water-jacketed chamber at $37^{\circ} \mathrm{C}$ in HEPES-KRP medium (50 mM HEPES, pH 7.4, $100 \mathrm{mM}$ $\mathrm{NaCl}, 5 \mathrm{mM} \mathrm{KCl}, 1 \mathrm{mM}$ each of $\mathrm{MgCl}_{2}, \mathrm{NaH}_{2} \mathrm{PO}_{4}$ and $\mathrm{CaCl}_{2}$ ) containing $1 \mathrm{mM}$ D-glucose. Aliquots of an NOsaturated solution were added to the reaction mixture at atmospheric oxygen tension [4].

Superoxide generation by E. faecalis was analyzed by the cytochrome $\mathrm{C}$ reduction method $[1,11]$. Reaction mixtures contained, in a total volume of $1 \mathrm{ml} \mathrm{PBS,} 1 \mathrm{mM}$ cytochrome c, $1 \mathrm{mM}$ glucose, 600 units of $\mathrm{Cu} / \mathrm{Zn}-\mathrm{SOD}$ and $1 \times 10^{8}$ cells/ $\mathrm{ml}$. The reaction was started by adding $E$. faecalis.

Western blot analysis was performed as described previously $[12,13]$. Briefly, cells were disrupted in a Y-Yeast Protein Extraction Reagent (PIERCE) and protease inhibitor cocktail (Nacalai tesque, Kyoto). Then, the lysates were centrifuged at $10,000 \times \mathrm{g}$ and $4^{\circ} \mathrm{C}$ for $10 \mathrm{~min}$, and fractionated into cytosol and particulates. Aliquots of cell lysates $(10 \mu \mathrm{g}$ of protein) were subjected to $10 \%$ sodium dodecyl sulfatepolyacrylamide gel electrophoresis (PAGE) followed by electroporation onto a polyvinylidene difluoride membrane (Millipore, Tokyo). The membrane specimens were treated with a blocking buffer (Nacalai tesque, Kyoto, Japan), reacted with nitro-tyrosine polyclonal antibody (Cell Signaling Technology Inc., MA), and subsequently with goat anti-rabbit IgG conjugated with horseradish peroxidase (Dako, Glostrup, Denmark). Then, the nitro-tyrosine of proteins was detected using an ECL plus kit (Amersham Pharmacia Biotech). The proteins were also stained with Coomassie brilliant blue R-250.

\section{Results}

\section{Superpxide generation by E. faecalis}

E. faecalis were incubated in $\mathrm{BHI}$ medium in the presence or absence of $2 \%$ glucose at $37^{\circ} \mathrm{C}$ for $4 \mathrm{~h}$. Then, the rate of superoxide generation was measured by using cytochrome $\mathrm{c}$ reduction method $[1,11]$. E. faecalis generated $\mathrm{O}_{2}{ }^{-}$at a rate of $0.5 \mathrm{nmol} / \mathrm{min} / 10^{8}$ cells in a glucose-dependent manner (Fig. 1). The presence of SOD strongly inhibited the reduction of cytochrome $\mathrm{c}$, suggesting the generation of superoxide radicals.

\section{Effect of $\mathrm{NO}$ on the growth, and $\mathrm{O}_{2}$ consumption}

NOC12 spontaneously releases $2 \mathrm{~mol} \mathrm{NO}$ per mol of the compound and, hence, it has been used as a useful NO donor [14]. Under the present experimental culture conditions, $E$. faecalis grow similarly in the presence or absence of $1 \mathrm{mM}$ glucose. However, the rate of growth slightly decreased thereafter in the absence of glucose. The growth of $E$. faecalis was inhibited by the presence of NOC12 either in the presence or absence of glucose (Fig. 2). The inhibitory effect of NOC12 depended on its concentration (data not 
A)

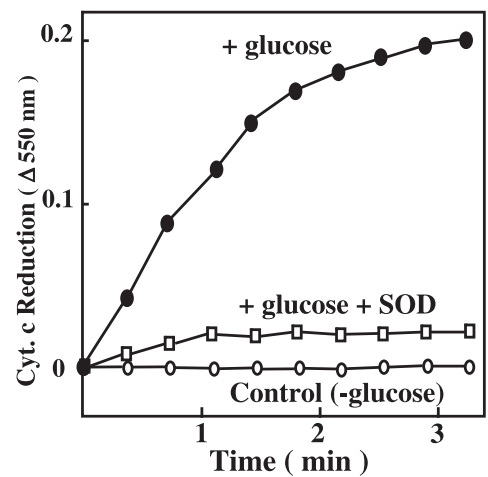

B)

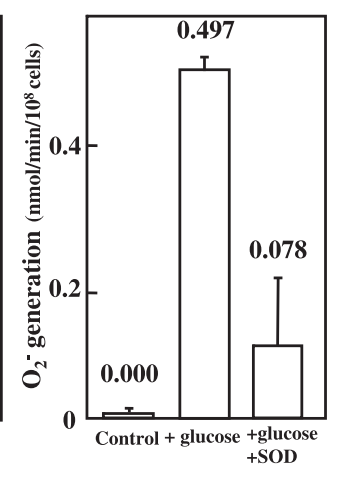

Fig. 1. Superoxide generation assessed by cytochrome c reduction. E. faecalis used in this study was RIMD 5803 (JCM5803) strain. E. faecalis were incubated in BHI medium (Difco) at $37^{\circ} \mathrm{C}$ and $\mathrm{pH} 7.5$ for overnight. The incubated cells $(\mathrm{OD}=0.1$ at $660 \mathrm{~nm})$ were inoculated into $100 \mathrm{ml} \mathrm{BHI} \mathrm{medium} \mathrm{and} \mathrm{cultured} \mathrm{with} \mathrm{shaking} \mathrm{at}$ $37^{\circ} \mathrm{C}$ and $\mathrm{pH} 7.5$ for $4 \mathrm{~h}$. Mid-log-phase incubates $(\mathrm{OD}=0.4-5$ at $660 \mathrm{~nm})$ were obtained and used. The incubated cells were centrifuged at $3000 \times \mathrm{g}$ and $4{ }^{\circ} \mathrm{C}$ for $10 \mathrm{~min}$, and washed once with PBS. Superoxide generation by $E$. faecalis was analyzed by the cytochrome c reduction method $[1,11]$. Reaction mixtures contained in a total volume of $1 \mathrm{ml}$ PBS, $1 \mathrm{mM}$ cytochrome $\mathrm{C}$, and $1 \times 10^{8}$ cells $/ \mathrm{ml}$ in the presence (open square) or absence (closed circle, open circle) of 600 units of $\mathrm{Cu} / \mathrm{Zn}-\mathrm{SOD}$. A) The reaction was started by adding E. faecalis in the presence (closed circle) or absence (open circle) of $1 \mathrm{mM}$ glucose at $37^{\circ} \mathrm{C}$. B) The rate of superoxide generation was calculated by cytochrome $\mathrm{C}$ reduction.

shown).

We previously reported that a low concentration of NO $(5 \mu \mathrm{M})$ inhibited the respiration of E. coli and rapidly decreased their ATP levels in a reversible manner [4]. However, the presence of NO had no appreciable effect on the oxygen consumption by E. faecalis (Fig. 3). To elucidate the mechanism of the NOC12-induced inhibition of cell growth, we also analyzed the effect of peroxynitrite, a reaction product of $\mathrm{O}_{2}{ }^{-}$and $\mathrm{NO}$, on the oxygen consumption by $E$. faecalis. The presence of peroxynitrite had no appreciable effect on their oxygen consumption.

Effect of long-term exposure to NO on the oxygen metabolism and growth of cells

To elucidate the mechanism of the inhibition of $E$. faecalis growth by NO, cells were incubated in the presence of NOC12 and glucose for $4 \mathrm{~h}$, washed with fresh medium to remove the remaining NO donor, and then cultured in the absence of NOC12. The washed cells rapidly grew at a similar rate to that of intact untreated cells (Fig. 4). Thus, the inhibitory effect of $\mathrm{NO}$ on the growth of E. faecalis is

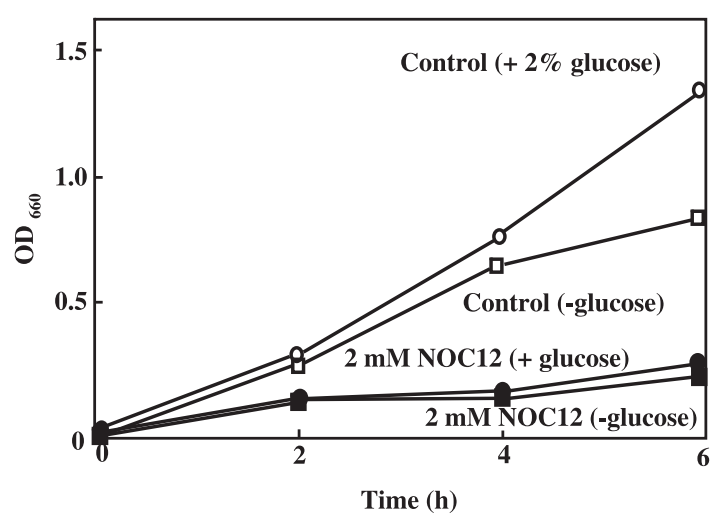

Fig. 2. Effect of NO on the growth of E. faecalis. E. faecalis of mid-log-phase incubates $(\mathrm{OD}=0.1$ at $660 \mathrm{~nm})$ were inoculated into $100 \mathrm{ml} \mathrm{BHI}$ medium and cultured with shaking in the presence (open circle) or absence (open square) of $1 \mathrm{mM}$ glucose at $37^{\circ} \mathrm{C}$ for $4 \mathrm{~h}$. The growth was inhibited by $2 \mathrm{mM}$ NOC12 in the presence (closed circle) and absence (closed square) of glucose.

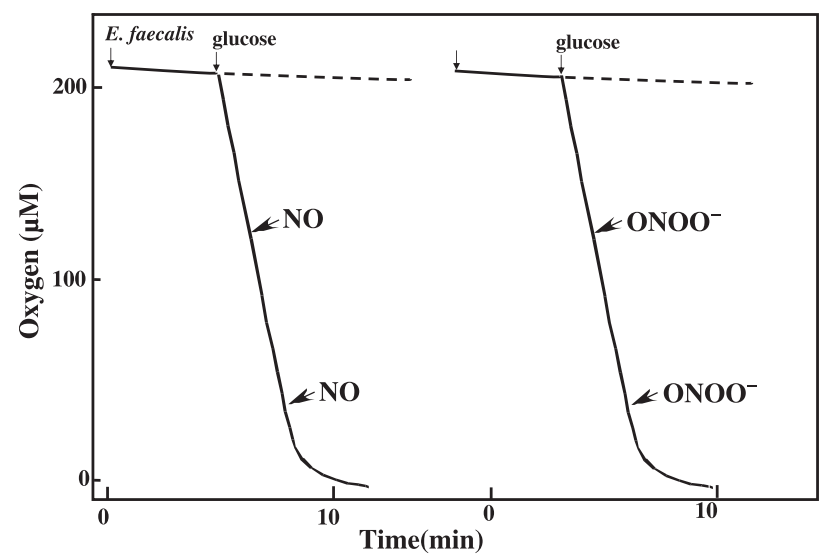

Fig. 3. Effect of $\mathrm{NO}$ and $\mathrm{ONOO}^{-}$on the $\mathrm{O}^{2}$ consumption by $E$. faecalis. Oxygen consumption by $E$. faecalis $\left(1 \times 10^{8}\right.$ cells $/ \mathrm{ml}$ ) was determined polarographically using a Clark type oxygen electrode fitted to a $2 \mathrm{ml}$ water-jacketed chamber at $37^{\circ} \mathrm{C}$ in HEPES-KRP medium $(50 \mathrm{mM}$ HEPES, pH 7.4, $100 \mathrm{mM} \mathrm{NaCl}, 5 \mathrm{mM} \mathrm{KCl}, 1 \mathrm{mM}$ each of $\mathrm{MgCl}_{2}, \mathrm{NaH}_{2} \mathrm{PO}_{4}$ and $\mathrm{CaCl}_{2}$ ) containing $1 \mathrm{mM}$ Dglucose. NO $(5 \mu \mathrm{M})$ or $\mathrm{ONOO}^{-}(10 \mu \mathrm{M})$ were added to the reaction mixture at various oxygen tension.

reversible under the present experimental conditions.

Although E. faecalis also consumed oxygen even after long term exposure to $\mathrm{NOC} 12$, the rate of its consumption was significantly lower than that of untreated intact cells (see Fig. 3 and Fig. 5). The presence of either NO $(5 \mu \mathrm{M})$ or peroxinitrite $\left(\mathrm{ONOO}^{-}\right)(10 \mu \mathrm{M})$ had no appreciable effect on the rate of oxygen consumption by the NOC12-pretreated cells. 


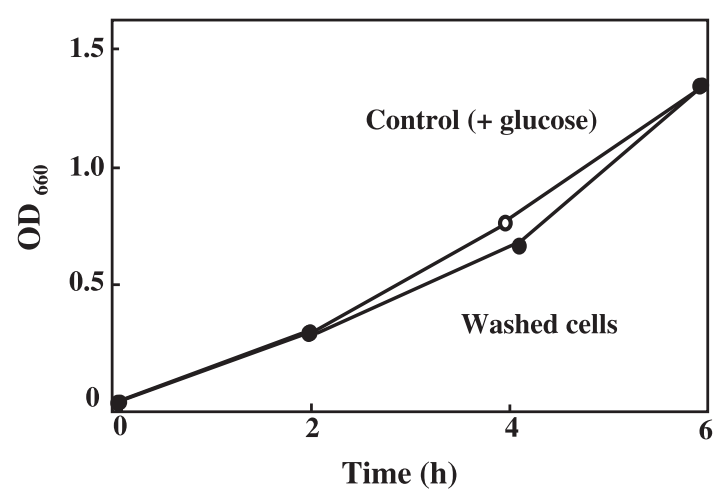

Fig. 4. Effect of long-term exposure to NO on E. faecalis. After E. faecalis was incubated in the presence (closed circle) or absence (open circle) of $2 \mathrm{mM} \mathrm{NOC12}$ and $1 \mathrm{mM}$ glucose for $4 \mathrm{~h}$, the cells washed with fresh medium to remove the remaining NO donor, and then cultured in the absence of NOC12.

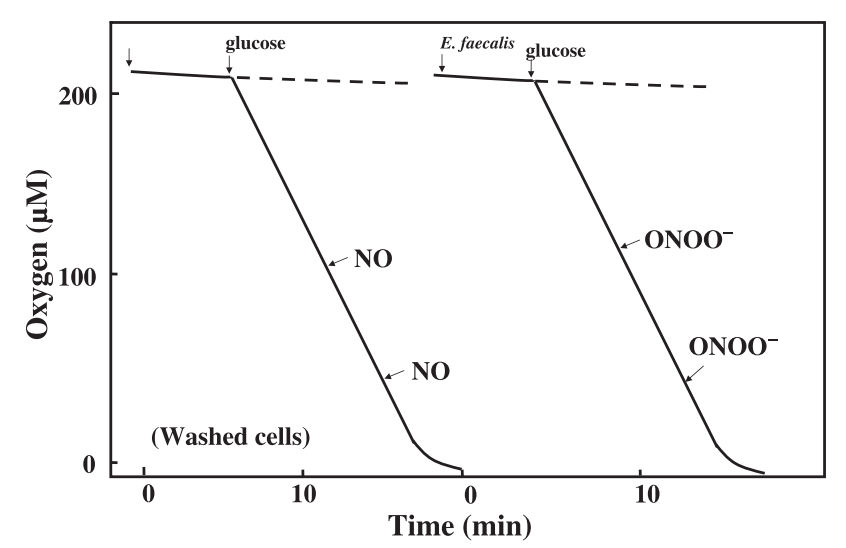

Fig. 5. Effect of long-term exposure to $\mathrm{NO}$ on the $\mathrm{O}^{2}$ consumption by $E$. faecalis. After $E$. faecalis was incubated in the presence of $2 \mathrm{mM}$ NOC12 and $1 \mathrm{mM}$ glucose for $4 \mathrm{~h}$, the cells washed with fresh medium to remove the remaining $\mathrm{NO}$ donor, and $\mathrm{O}^{2}$ consumption was measured on the same condition as Fig. 3. NO $(5 \mu \mathrm{M})$ or $\mathrm{ONOO}^{-}$ $(10 \mu \mathrm{M})$ were added to the reaction mixture at various oxygen tension.

\section{The mechanism of protein nitration in cells}

To elucidate the mechanism for the inhibition of oxygen consumption and growth of E. faecalis by $\mathrm{NOC12}$, the pretreated cells were washed and fractionated into cytoplasm and particulate fractions. Upon SDS-PAGE followed by Western blotting, various protein bands in NOC12treated cells were found to react with polyclonal antibody against nitro-tyrosine (Fig. 6). Nitrotyrosine-positive protein bands were found more markedly with the cytosolic fraction than with the particulate fraction.

It has been well documented that NO rapidly reacts with

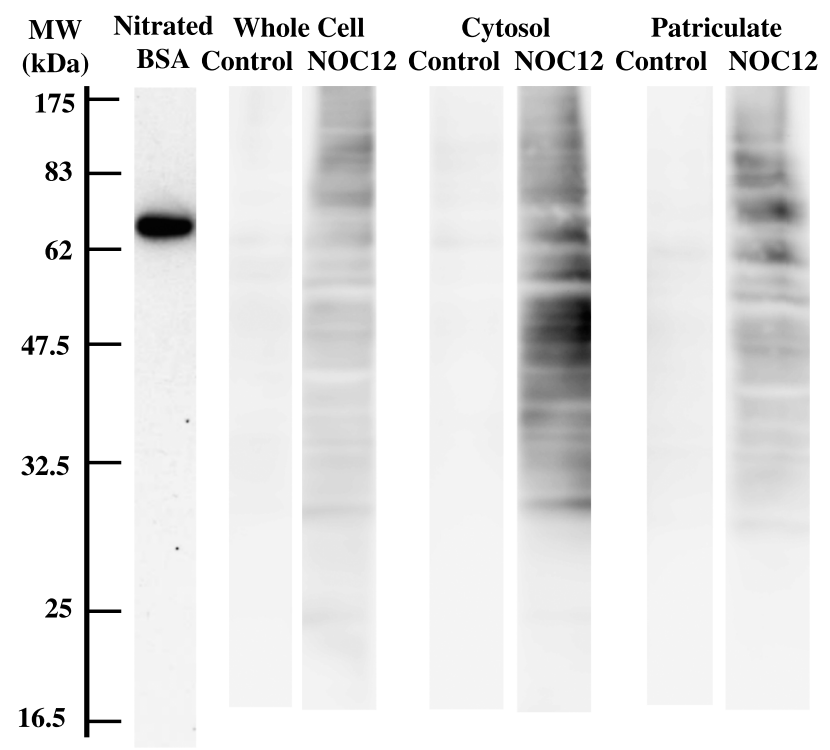

Fig. 6. Detection of nitrotyrosine in E. faecalis proteins. E. faecalis was incubated in the presence or absence of $2 \mathrm{mM}$ NOC12 for $4 \mathrm{~h}$. The cells were washed and fractionated into cytoplasm and particulate fractions. Total and fractionated proteins $(10 \mu \mathrm{g})$ were subjected to SDS-PAGE followed by western blot analysis using antinitrotyrosine antibody. Nitrated BSA (peroxynitiritetreated BSA) is a positive control for detection of protein tyrosine nitration. MW, molecular weight (kilodalton)

the superoxide radical to form anionic $\mathrm{ONOO}^{-}$. Since the superoxide radical was detected by the cytochrome $\mathrm{c}$ reduction method $[1,11]$, this radical would have reacted with $\mathrm{NO}$ extracellularly to generate $\mathrm{ONOO}^{-}$. Thus, the extracellular $\mathrm{ONOO}^{-}$would have entered into cells prior to catalyze the nitration of proteins preferentially in cytoplasm. To understand the mechanism for the preferential nitration of cytosolic proteins in E. faecalis, we analyzed the effect of 4,4'-diisothiocyanatostilbene-2,2'-disulfonic acid (DIDS), a specific inhibitor of anion transporters [15], on protein nitration in E. faecalis. Western blotting analysis revealed that the presence of DIDS strongly inhibited the occurrence of nitrated proteins both in cytoplasm and particulate fractions (Fig. 7).

To evaluate the role of protein nitration in the mechanism of reversible inhibition of $E$. faecalis growth by NO, possible involvement of the denitration of the modified proteins in cells was studied. After incubation with $2 \mathrm{mM}$ NOC12 and $1 \mathrm{mM}$ glucose for $4 \mathrm{~h}$, the cells were washed with fresh medium and subsequently cultured for $\sim 60 \mathrm{~min}$ in NOC12-free medium. Western blotting analysis of the cell fractions revealed that the nitrotyrosine-positive protein bands in NOC12-pretreated cells disappeared rapidly after incubation (Fig. 8). As nitration of tyrosyl residues in proteins occurred in an irreversible manner, its disappearance 


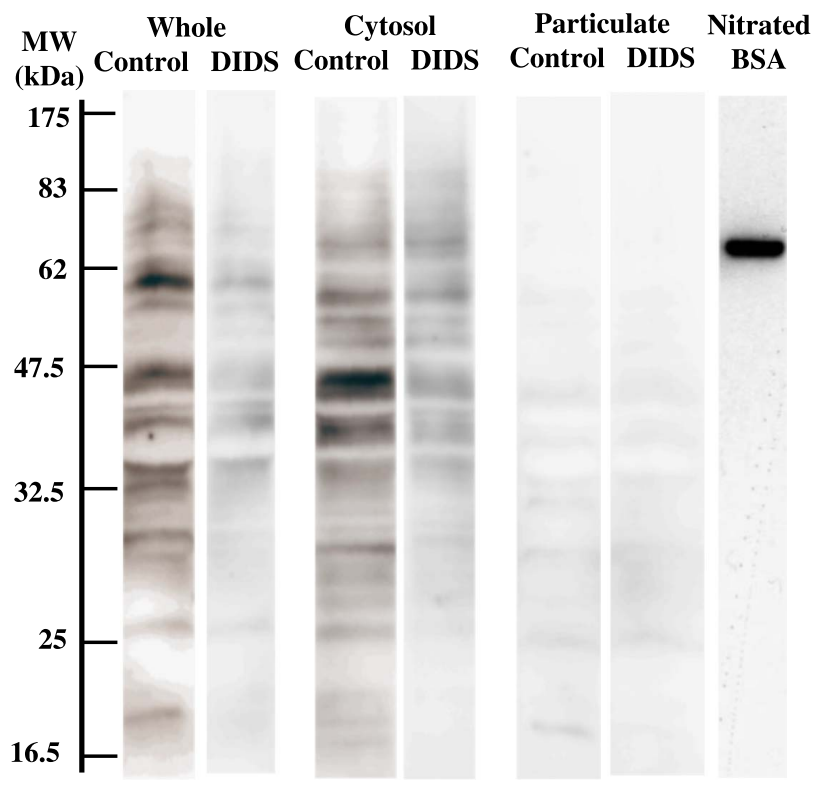

Fig. 7. Effect of DIDS on protein nitration in E. faecalis. After E. faecalis was incubated with $300 \mu \mathrm{M}$ DIDS in PBS included $1 \mathrm{mM}$ glucose and $2 \mathrm{mM}$ NOC12 for $20 \mathrm{~min}$, E. faecalis was incubated in the presence of $2 \mathrm{mM}$ NOC12 for $4 \mathrm{~h}$. The cells were washed and fractionated into cytoplasm and particulate fractions. SDS-PAGE followed by western blotting was performed by the same way as Fig. 7. Nitrated BSA (peroxynitirite-treated BSA) is a positive control for detection of protein tyrosine nitration. MW, molecular weight (kilodalton) might depend on cell growth. Alternatively, the nitrated proteins might be rapidly eliminated by proteolysis.

\section{Discussion}

The present work describes that $\mathrm{NO}$ reacted with $\mathrm{O}_{2}^{-}$ generated by $E$. faecalis to form peroxynitrite that preferentially nitrated tyrosyl residues in cytosolic proteins and inhibited the growth of E. faecalis without affecting their oxygen metabolism and ATP synthesis. Kinetic analysis revealed that nitration of tyrosyl residues in cells was inhibited by DIDS, a specific inhibitor of anion transporter, suggesting that superoxide anion and/or peroxynitrite might entered into cells via DIDS-sensitive anion transporter and preferentially modified cytosolic proteins in E. faecalis. When cultured in the absence of NO donor, the nitrotyrosyl proteins formed in E. faecalis rapidly disappeared.

E. faecalis is an anaerobic bacteria that preferentially lives in the intestine. Although the oxygen tensions in the intestine are fairly low, this pathogen contains quinol oxidase/ cytochrome bd that generates the superoxide radical [16]. Biochemical analysis revealed that E. faecalis consumed molecular oxygen at a rate of $1.25 \mathrm{nmol} / \mathrm{min} / 10^{8}$ cells and generated the superoxide radical at a rate of $0.5 \mu \mathrm{mol} / \mathrm{min} /$ $10^{8}$ cells under the present experimental conditions. Huycke et al. [10] reported that E. faecalis generates superoxide radicals using oxidoreductase, the active site of enzyme responsible for the one-electron reduction of molecular oxygen is localized extracellularly. This observation is

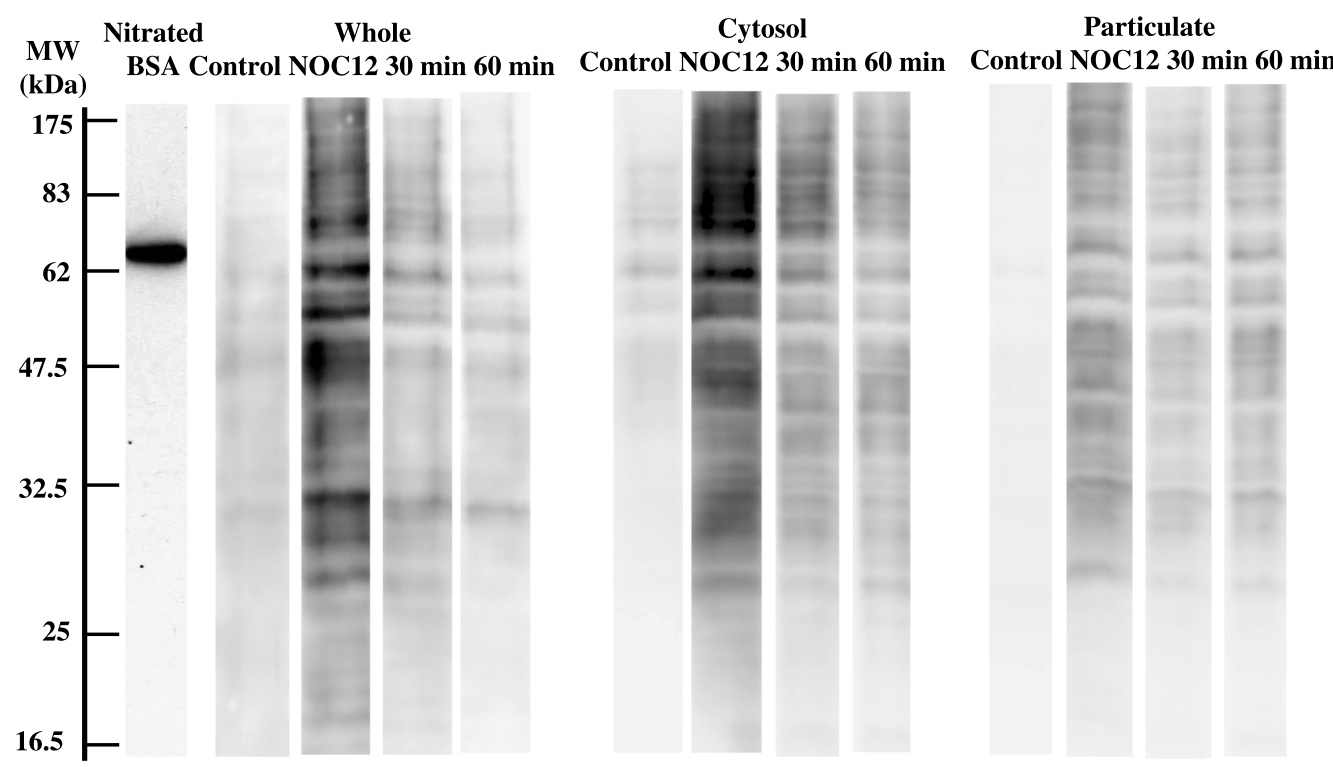

Fig. 8. Denitration of NO-treated E. faecalis. After incubation with $2 \mathrm{mM}$ NOC12 and $1 \mathrm{mM}$ glucose for $4 \mathrm{~h}$, E. faecalis was washed with fresh medium and subsequently cultured for $\sim 60 \mathrm{~min}$ in NOC12-free medium. The cells were washed and fractionated into cytoplasm and particulate fractions. SDS-PAGE followed by western blotting was performed by the same way as Fig. 7. Nitrated BSA (peroxynitirite-treated BSA) is a positive control for detection of protein tyrosine nitration. MW, molecular weight (kilodalton) 
consistent with the present finding that about $40 \%$ of molecular oxygen consumed was detected as the superoxide radical by using extracellularly added cytochrome c.

Since anaerobic E. faecalis also contains Mn-SOD, both superoxide and hydrogen peroxide would have occurred in and around this pathogen. The reason why anaerobic $E$. faecalis generates such reactive oxygen species remains unclear. We previously reported that $H$. pylori and $S$. mutans also generate substantial amounts of superoxide $[2,6]$. These bacteria also showed strong resistance to NO and related metabolites. These observations suggest that the bacteria use reactive oxygen species as machineries for their survival against host defense mechanisms and/or establishing a niche against other bacteria [1].

We previously reported that NO reversibly interacts with terminal oxidases in electron transport system of mitochondria, E. coli and heme-containing manmalian cells, thereby inhibiting their respiration and energy transduction [17-20]. It should be noted that E. faecalis lacks enzymes required for the synthesis of heme and respiration by cytochrome $b d[10]$. Thus, it is not surprising that NO failed to inhibit the oxygen consumption by E. faecalis. Incubation of E. faecalis with NOC12 increased cellular levels of nitortyrosyl proteins preferentially in cytoplasma. Thus, NO and/or its metabolite(s) would have been entered into cells prior to nitration of plasma proteins. It should be noted that both superoxide and peroxynitrite are anions that are difficult to penetrate through membrane/lipid bilayers. Since the reactivity of superoxide and NO is extremely high, reaction of the two radicals seem to occur extracellularly. Thus, peroxynitrite generated extracellularly would have entered into cells via an anion transport system of $E$. faecalis and then reacted with proteins in cytoplasm and membranes. Alternatively, some fraction of superoxide generated extracellularly would have entered into cells and reacted with NO (which easily diffuses across membranes) to form peroxynitrite. Peroxynitrite occurring in cells would have reacted with tyrosyl residues of proteins both in cytoplasm and membranes. This hypothesis is consistent with the finding that protein nitration was significantly inhibited by pretreating cells with DIDS, an affinity labeling agent for anion transporter. Lufrano et al. [15] also reported that the transport of peroxynitrite across platelet membranes via $\mathrm{HCO}_{3}{ }^{-} /$ $\mathrm{Cl}^{-}$transporter was successfully inhibited by DIDS.

The present work shows that treatment of E. faecalis with NO donor inhibited their growth in a reversible manner. Molecular mechanism for the growth inhibition of $E$. faecalis is not known at present. Nitration of these proteins often impairs cell functions and sometimes induces cell death. We previously showed that NO also inhibited the growth of $E$. coli and a variety of mammalian cells [4, 18]. It should be noted that peroxynitrite causes nitration of a wide variety of proteins including those in mitochondria, such as Mn-SOD (45 kD), aconitase, cytochrome c, voltagedependent anion channel and ATPase [21]. Poly ADP ribosylating protein $(43-53 \mathrm{kD})$ is present in various bacteria including Alicyclobacillus, Bacillus and Thermus genera, and thermophiic aerobic bacteria [22]. Thus, nitration of these proteins might affect the growth of E. faecalis. Since the nitrated protein bands in Fig. 9 involve proteins whose molecular size were similar to those of the polymerases (160 kD and 43-58 kD), functions of the enzymes would be impaired in NO-treated cells. Since the growth rate of $E$. faecalis recovered to a control level after incubation of cells with NO-free medium with concomitant disappearance of the nitrated proteins, the nitrated proteins might involve important factor(s) that play a role in the regulation of cell growth. Identification and analysis of functions of the nitrated proteins should be studied further.

Although E. faecalis survives in phagosomes of macrophages, its molecular mechanism remains unknown. In this context, Trypanosoma cruzi has been known to use trypanothione-thiol system for the detoxification of peroxynitrite [23]. Since E. faecalis also possesses the gene encoding thiol peroxidase (Tpx) [24], this pathogen may also use the enzyme system to detoxify peroxynitrite for the survival in macrophages. The properties of the nitrated proteins in cytoplasm and membranes and possible roles of thiol peroxidase in the regulation of cell growth and survival of E. faecalis were under our current investigation.

\section{References}

[1] Babior, B.M., Kipnes, R.S., and Curnutte, J.T.: Biological defense mechanisms. The production by leukocytes of superoxide, a potential bactericidal agent. J. Clin. Invest., 52, 741-744, 1973.

[2] Sato, E.F., Choudhury, T., Nishikawa, T., and Inoue, M.: Dynamic aspect of reactive oxygen and nitric oxide in oral cavity. J. Clin. Biochem. Nutr., 42, 8-13, 2008.

[3] Inoue, M., Sato, E.F., Nishikawa, M., Park, A.M., Kira, Y., Imada, I., and Utsumi, K.: Cross talk of nitric oxide, oxygen radicals, and superoxide dismutase regulates the energy metabolism and cell death and determines the fates of aerobic life. Antioxid. Redox Signal, 5, 475-484, 2003.

[4] Yu, H., Sato, E.F., Nagata, K., Nishikawa, M., Kashiba, M., Arakawa, T., Kobayashi, K., Tamura, T., and Inoue, M.: Oxygen-dependent regulation of the respiration and growth of Escherichia coli by nitric oxide. FEBS Lett., 409, 161$165,1997$.

[5] Cooper, C.E.: Nitric oxide and cytochrome oxidase: substrate, inhibitor or effector? Trends Biochem. Sci., 27, 33-39, 2002.

[6] Nagata, K., Yu, H., Nishikawa, M., Kashiba, M., Nakamura, A., Sato, E.F., Tamura, T., and Inoue, M.: Helicobacter pylori generates superoxide radicals and modulates nitric oxide metabolism. J. Biol. Chem., 273, 14071-14073, 1998.

[7] Brown, J.F., Tepperman, B.L., Hanson, P.J., Whittle, B.J., and Moncada, S.: Differential distribution of nitric oxide 
synthase between cell fractions isolated from the rat gastric mucosa. Biochem. Biophys. Res. Commun., 184, 680-685, 1992.

[8] Calatayud, S., Barrachina, D., and Esplugues, J.V.: Nitric oxide: relation to integrity, injury, and healing of the gastric mucosa. Microsc. Res. Tech., 53, 325-335, 2001.

[9] Verneuil, N., Maze, A., Sanguinetti, M., Laplace, J.M., Benachour, A., Auffray, Y., Giard, J.C., and Hartke, A.: Implication of (Mn)superoxide dismutase of Enterococcus faecalis in oxidative stress responses and survival inside macrophages. Microbiology, 152, 2579-2589, 2006.

[10] Huycke, M.M., Moore, D., Joyce, W., Wise, P., Shepard, L., Kotake, Y., and Gilmore, M.S.: Extracellular superoxide production by Enterococcus faecalis requires demethylmenaquinone and is attenuated by functional terminal quinol oxidases. Mol. Microbiol., 42, 729-740, 2001.

[11] Ushijima, Y. and Nakano, M.: No or little production of singlet molecular oxygen in $\mathrm{HOC} 1$ or $\mathrm{HOC} 1 / \mathrm{H} 2 \mathrm{O} 2$ a model system for myeloperoxidase/H2O2/C1. Biochem. Biophys. Res. Commun., 93, 1232-1237, 1980.

[12] Choudhury, T., Sato, E.F., and Inoue, M.: Nitrite reductase in Streptoccocus mutans plays a critical role in the survival of this pathogen in oral cavity. Oral Microbiol. Immunol., 22, 384-389, 2007.

[13] Nakamura, A., Park, A., Nagata, K., Sato, E.F., Kashiba, M., Tamura, T., and Inoue, M.: Oxidative cellular damage associated with transformation of Helicobacter pylori from a bacillary to a coccoid form. Free Radic. Biol. Med., 28, 1611-1618, 2000.

[14] Hayashi, K., Noguchi, N., and Niki, E.: Action of nitric oxide as an antioxidant against oxidation of soybean phosphatidylcholine liposomal membranes. FEBS Lett., 370, 37-40, 1995.

[15] Lufrano, M. and Balazy, M.: Interactions of peroxynitrite and other nitrating substances with human platelets: the role of glutathione and peroxynitrite permeability. Biochem. Pharmacol., 65, 515-523, 2003.

[16] Barja, G.: Mitochondrial oxygen radical generation and leak: sites of production in states 4 and 3 , organ specificity, and relation to aging and longevity. J. Bioenerg. Biomembr., 31, 347-366, 1999.

[17] Takehara, Y., Kanno, T., Yoshioka, T., Inoue, M., and Utsumi, K.: Oxygen-dependent regulation of mitochondrial energy metabolism by nitric oxide. Arch. Biochem. Biophys., 323, 27-32, 1995.

[18] Takehara, Y., Nakahara, H., Inai, Y., Yabuki, M., Hamazaki, K., Yoshioka, T., Inoue, M., Horton, A.A., and Utsumi, K.: Oxygen-dependent reversible inhibition of mitochondrial respiration by nitric oxide. Cell Struct. Funct., 21, 251-258, 1996.

[19] Okada, S., Takehara, Y., Yabuki, M., Yoshioka, T., Yasuda, T., Inoue, M., and Utsumi, K.: Nitric oxide, a physiological modulator of mitochondrial function. Physiol. Chem. Phys. Med. NMR., 28, 69-82, 1996.

[20] Nishikawa, M., Sato, E.F., Utsumi, K., and Inoue, M.: Oxygen-dependent regulation of energy metabolism in ascites tumor cells by nitric oxide. Cancer Res., 56, 45354540, 1996.

[21] Radi, R., Cassina, A., Hodara, R., Quijano, C., and Castro, L.: Peroxynitrite reactions and formation in mitochondria. Free Radic. Biol. Med., 33, 1451-1464, 2002.

[22] Faraone-Mennella, M.R., De Maio, A., Petrella, A., Romano, M., Favaloro, P., Gambacorta, A., Lama, L., Nicolaus, B., and Farina, B.: The (ADP-ribosyl)ation reaction in thermophilic bacteria. Res. Microbiol., 157, 531-537, 2006.

[23] Thomson, L., Denicola, A., and Radi, R.: The trypanothionethiol system in Trypanosoma cruzi as a key antioxidant mechanism against peroxynitrite-mediated cytotoxicity. Arch. Biochem. Biophys., 412, 55-64, 2003.

[24] La Carbona, S., Sauvageot, N., Giard, J.C., Benachour, A., Posteraro, B., Auffray, Y., Sanguinetti, M., and Hartke, A.: Comparative study of the physiological roles of three peroxidases (NADH peroxidase, Alkyl hydroperoxide reductase and Thiol peroxidase) in oxidative stress response, survival inside macrophages and virulence of Enterococcus faecalis. Mol. Microbiol., 66, 1148-1163, 2007. 